\title{
Converting Mrs Crouch: Women, Wonders and the Formation of English Methodism, I738-I 74 I
}

\author{
by BRIAN GURTIS CLARK and JOANNA CRUICKSHANK \\ Windsor, Connecticut \\ Deakin University \\ E-mails: Bcurtisclark@gmail.com \\ joanna.cruickshank@deakin.edu.au
}

This article examines the development of English Methodism during the formative period between I 738 and I 74I, focusing upon the experiences of women, who made up the majority of Methodists both at this time and through much of the movement's history. In particular, the role that women and questions of gender played in the conflict between the Wesley brothers and the Moravian leadership in London is considered. Using accounts written by the male leaders of both groups and the women who supported them, it is argued that women's choices determined the outcome of this early battle, shaping the nascent movement in crucial ways.

$\mathrm{n} 20$ September 1739 the young Anglican priest John Wesley met
with a woman named Mrs Crouch, whom he described as being 'in
deep heaviness'. As he recorded in his journal:

She had long earnestly desired to receive the Holy Communion, having an unaccountably strong persuasion that God would manifest himself to her therein and give rest to her soul. But her heaviness being now greatly increased, Mr. D[elamott]e gave her that fatal advice not to communicate till she had living faith. This still added to her perplexity. Yet at length she resolved to obey God rather than man. And 'he was made known unto her in breaking of bread.' In that moment she felt her load removed; she knew she was accepted in the Beloved. ${ }^{1}$

CWJ = The manuscript journal of the Reverend Charles Wesley, M. A., ed. S. T. Kimbrough, Jr, and Kenneth G. C. Newport, Nashville 2008; EMV = Early Methodist volume, Methodist Archives and Research Centre, John Rylands University Library, Manchester.

1 The works of John Wesley, ed. W. Reginald Ward and Richard P. Heitzenrater, Nashville 1990, xix. $9^{8}$. 
The spiritual experience of Mrs Crouch was only one of many that Wesley recorded in his journal that year. In the previous week alone he had noted incidents of people groaning, sighing, collapsing and seeing visions while he addressed them. Among this list of extraordinary emotional responses, Mrs Crouch's sense of being given 'rest to her soul' may not stand out. None the less, it was an event of great importance. Mrs Crouch's conversion represented victory in one highly significant battle, in a war that Wesley was fighting against both the devil and more tangible opponents.

This article examines the development of English Methodism during the formative and conflict-ridden period of $173^{8-41}$, focusing particularly on the experiences and choices of women. Women made up the majority of Methodists, both during this period and as the movement grew and spread. ${ }^{2}$ As Phyllis Mack has recently noted, however, the 'response of secular scholars to this well-known fact of Methodist history has been to insist on the centrality of feminine (or anti-masculine) elements in the movement while almost totally ignoring the thinking and behaviour of actual women'.3 Alternatively, less secular scholars have sometimes been inclined to imagine the heavy involvement of women in early Methodism as an appealingly Edenic element in its origins. By contrast, this article explores the role that 'actual women' played in the sometimes ferocious conflicts that shaped early Methodism, particularly that between the Wesley brothers and those seeking to subsume the English revival movement within Moravian Pietism.

This article examines the experience of women during this period from three related perspectives: first, the broader significance given to women in John and Charles's accounts of their ministry in 1738-9, noting particularly the apparent relationship in these accounts between supernaturalism and gender; second, the ways in which women were represented in descriptions of the split within the Fetter Lane Society, by both the Wesleys and the Moravian leadership; finally, by means of an examination of a group of Methodist women's own accounts of their experience during this period, analysing their descriptions of the choices that they made at this time of conflict. From these multiple perspectives an argument is made for a new understanding of this important period.

\section{Wonders, women and the Wesleys}

The spiritual turmoil of Mrs Crouch in September 1739 reflected broader developments among Evangelicals in eighteenth-century London. The late 1730 saw the formation of a loosely organised network, which had

${ }^{2}$ See David Hempton, Methodism: empire of the spirit, New Haven-London 2005, 5 .

3 Phyllis Mack, Heart religion in the British Enlightenment: gender and emotion in early Methodism, Cambridge 2008, 19. 
emerged out of Oxford Methodism, the London Religious Societies, George Whitefield's preaching crusades and the influence of German Moravians.4 Most among this network shared certain convictions: that the 'new birth' was necessary, that it could be experientially verified, that it should lead to inner transformation and that it should be explained in terms of 'salvation by faith alone'. However, alongside these areas of agreement there were several competing theological schemes floating about the movement, sponsored by particular leaders, including the Wesley brothers, Whitefield and those leaders most influenced by German Moravianism, such as James Hutton.

Among these leaders, the Wesleys were particularly inclined toward a style of personal ministry that revolved around spiritual deliverances. As Henry Rack has shown, John Wesley's leadership within early Evangelicalism cannot be understood without an appreciation of the extent to which his ministry was profoundly and avowedly steeped in the supernatural. 5 A representative anecdote from this early period records his dealings with a young woman whom he found in the workhouse belonging to the parish of St Thomas's, Oxford, on 5 December 1738 :

At St Thomas's was a young woman, raving mad, screaming and tormenting herself continually. I had a strong desire to speak to her. The moment I began she was still. The tears ran down her cheeks all the time I was telling her, 'Jesus of Nazareth is able and willing to deliver you.' $\mathrm{O}$ where is faith upon the earth? Why are these poor wretches left under the open bondage of Satan? Jesus, Master! Give thou medicine to heal their sickness and deliver those who are now vexed with unclean spirits $!^{6}$

In this account, Wesley encountered a young woman whom he diagnosed as suffering under demonic oppression, and felt a 'strong desire to speak to her', a description which was meant to hint at divine leading. His message calmed her and this calm was presented as evidence of her deliverance from demonic oppression in the name of Jesus. Through this spiritual rescue, Wesley was able to demonstrate for his readers both the reality of miraculous deliverances and his own ability to effect them.

Significantly, like the vast majority of the cases of healing, deliverance or dramatic conversion found in Wesley's journal accounts for this period, this one involved a woman. Between this encounter and the end of the following year, Wesley described many such episodes in his journal: of the fifty-four in which he gave the sex of the person delivered, thirty-seven were women. 7 This is particularly notable given Richard Heitzenrater's intriguing finding, in his comparison of Wesley's unpublished diary and

4 See Henry D. Rack, Reasonable enthusiast: John Wesley and the rise of Methodism, London 1989, $15^{8-202 .}{ }^{5}$ Ibid. $387-8,43^{1-6 .}{ }^{6}$ Works of John Wesley, xix. 23.

7 See John Wesley's Journal, Dec. 1738-Dec. 1739, ibid., xix. 
published journal from 1736 , that in published accounts Wesley clearly downplayed the predominance of women among those to whom he ministered. Whereas in the unpublished diary, women were mentioned four times more often than men, in the published account, men were mentioned ten times more often than women. Wesley went so far as to masculinise the names and pronouns of women mentioned in his narrative. ${ }^{8}$ Heitzenrater's study focuses on Wesley's period in America, and his finding may reflect Wesley's sensitivity to the scandal involving Sophie Hopkey in which he became embroiled while in Georgia. None the less, it suggests that less than two years later Wesley was unlikely to over-emphasise the presence of women among those to whom he ministered.9

This role as spiritual deliverer was certainly not unique to John Wesley, though he was perhaps its most prominent practitioner. The journals of Charles Wesley are also full of such deliverances, and Charles's hymns from this period were written in support of the message of experiential grace that was the basis of this style of ministry. These hymns provided pastoral tools by means of which spiritual experiences could be invoked, shaped and remembered. On 10 July 1738 Charles recorded one of many similar accounts:

In going to Mr Chapman's I met Margaret Beutinman, and bade her follow, for we were several of us to join in prayer there. James Hutton, Mr Holland, Mr and Mrs Sims got hither soon after us. We sang, and pleaded the promises. In the midst of prayer, Margaret received the atonement, and professed her faith without wavering; her love to Christ, and willingness to die at that moment. We returned thanks for her, and I then ... heard Mrs Storer, a sister of Mr Bray's, complain of the hardness of her heart. She owned she had been under the utmost uneasiness, since our last meeting at her brother's, unable to pray, or find any rest to her soul. While we were singing the hymn to the father, she did find the rest she sighed after; was quite pierced, as she said, her heart ready to burst, and her whole nature overpowered ... Her faith was further confirmed by public prayer. ${ }^{10}$

This is an extraordinarily rich account. Margaret Beutinman met with a group of leaders in the movement. They sang a hymn, and "pleaded the promises' that God would bring conversion to seeking souls. Margaret responded to these prompts by attesting that she had 'received the atonement' and was now possessed of great love for Christ.

Mrs Storer, perhaps moved by her example, complained of 'hardness of heart' - a spiritual condition that involved the inability emotionally to

8 Richard Heitzenrater, 'The second rise of Methodism: Georgia', Methodist History xxviii (1990), 131.

9 Charles Wesley's unpublished diary for $1739-41$ is primarily a record of meetings and rarely includes mention of specific deliverances, which makes it impossible to undertake a similar study of the gender balance among those delivered in this period.

10 CWJ, $133-4$. 
experience gospel truths, manifest in her difficulty in prayer and lack of peace. The assembly worked to remedy this crisis by singing a hymn. John Tyson's research suggests that the hymn in question was one of Charles's own, which imagined the singer as prodigal son and God as loving Father:

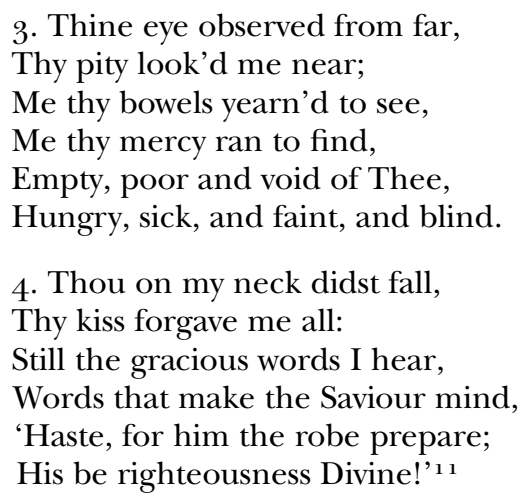

The singing produced a gratifying result, since Mrs Storer felt herself 'quite pierced' while reliving the power of the Father's acceptance of the prodigal. Her experience at public prayer further confirmed the validity of this experience. In this account, two women testified to the emotional eruptions that were held reliably to signify the saving work of God in the soul, in the context of a group that actively fostered these experiences and was deeply concerned with 'confirming' them as accurate perceptions of important spiritual changes.

These representative accounts point to a number of notable features of the Wesleyan movement in its earliest years. The Wesleys expected and relied upon such experiences to provide evidence of the doctrines that they taught and to confirm their own authority. The practices that they adopted in their ministry-individual counselling, intensive prayer and reading of Scripture within small groups, and the writing and use of hymns as pastoral tools-allowed such experiences to be evoked and shaped. ${ }^{12}$ Less obvious is that in the Wesleys' accounts it was women who most often and most spectacularly displayed such experiential confirmation of Wesleyan teaching. ${ }^{13}$

11 John R. Tyson (ed.), Charles Wesley: a reader, Oxford 1989, 121.

12 For more on the function of Charles Wesley's hymns within early Methodism see Joanna Cruickshank, Pain, passion and faith: revisiting the place of Charles Wesley in early Methodism, Lanham, MD 2009.

${ }^{13}$ In Charles Wesley's journal for 1738 , he identifies fifty-five women who experienced deliverance under his ministry, in comparison with thirty-six men: $C W J \mathrm{i}$. 


\section{The Wesleys and the Moravians}

The religious network described in such accounts was tight-knit, operating on an intimate scale as members gathered in homes for prayer and song. The very intimacy of the movement ensured that conflicts within the society would take place at close quarters, between people who knew each other well. In fact, at least three men named in the accounts above would become Moravian partisans; James Hutton and John Bray would lead the pro-Moravian party within the Fetter Lane Society, with the support of William Holland and other men who rejected both the authority and ministry practice of the Wesleys.

As many historians have noted, the Wesleys had been strongly influenced by Moravians, whom they had first encountered during their missionary venture to America. The Wesleys had accepted a broadly Moravian understanding of the necessity of personal conversion, evidenced by the experiential assurance of sins forgiven, and both John and Charles had undergone this experience in May 1738. In the same month the Wesleys had supported the establishment of the Fetter Lane Society in London, at the home of James Hutton, under the auspices of the Moravian leader, Peter Böhler, who had been instrumental in the Wesleys' Evangelical conversions. ${ }^{14}$

Soon afterwards, John Wesley embarked on a pilgrimage to Herrnhut and the other Moravian settlements in Europe. His correspondence during and after this journey expressed both his attraction to the love, unity and meekness that he saw displayed in these communities and his less positive reactions to the degree of individual passivity and social control that seemed to be associated with these characteristics. These reservations were apparently mutual: in Herrnhut, Wesley was reportedly 'excluded from the Lord's Table because he had not attained the full assurance of faith'. ${ }^{15}$

On his return from Herrnhut, Wesley penned an (unsent) letter to the Moravians there, containing a long list of pointed questions, including:

Do you not wholly neglect joint fasting?

Is not the Count [Zinzendorf]

all in all? Are not the rest mere shadows?...

Do you not magnify your own church too much?...

Are you not straitened in your love? Do you love your enemies and wicked men as yourselves?...

Are you not of a close, dark, reserved temper and behaviour? ${ }^{16}$

As a whole, the questions demonstrated Wesley's discomfort with key aspects of Moravian culture-the enormous authority wielded by Zinzendorf, the emphasis on secrecy at Herrnhut, and the lack of the

${ }^{14}$ See Colin Podmore, Moravian Church in England, I728-176o, Oxford 1998, $3^{6-41 .} \quad{ }_{15}$ Works of John Wesley, xviii. 280 n. $3^{0 .}{ }_{16}$ Ibid. xxv. $5^{66-7 .}$ 
ascetic discipline and charitable outreach that Wesley had absorbed from his High Church Anglican heritage.

Back in England, these differences in practice would become more sharply focused. At the end of September $173^{8} \mathrm{John}$ Wesley returned to a small but growing revival network in London. He noted that the Fetter Lane Society included fifty-six men, who had been organised into eight 'bands', but there were only small bands of women. ${ }^{17}$ The Wesleys were among the leaders who constantly circulated around nightly meetings that ranged in numbers from the twenties to the hundreds. Other leaders included a number of German Moravians, whose role Wesley underplayed in his accounts of this period in order to create the impression that he controlled the Fetter Lane Society until the open conflicts of $1739 .{ }^{18}$

In addition to the German Moravians involved, a number of the English leaders of the Fetter Lane Society, including James Hutton and Benjamin Ingham, consistently sought to follow the Moravians and the models provided by their communities. At every turn John Wesley opposed them. ${ }^{19}$ One key issue was mentioned by Hutton in a letter written on 23 November 1738 :

Some persons had been ensnared, and many more were likely to be, by the too familiar intercourse at societies with young women ... Some people also, the present archbishop especially some time since, took offense at the promiscuous meeting of persons of both sexes, and themselves pointed out the regulations we are come to on that head, viz., that the women, married and unmarried, meet by themselves, excepting only the husbands of any of them with their wives and the ministers or he that expounds. ${ }^{20}$

The establishment of gender-segregated meetings was a Moravian convention, a solution to the ever-present danger that the emotional intimacy of society and band meetings would produce illicit liaisons. The Moravians had a strong tradition of parallel structures for men and women, in which separate men's and women's groups were pastored by leadership of each sex. This structure reflected a certain gender egalitarianism and provided opportunities for women to lead, but in London it would prove to be a relative handicap in attracting women to Moravianism.

Though Wesley supported the formation of smaller, single-sex classes within the Society, he strongly objected to the attempt to exclude women from the main meetings, writing that 'I do very exceedingly disprove of the excluding women when we meet to pray, sing and read the scriptures. I wish it might not be done before we have talked together.' ${ }^{21}$ This issue

17 Ibid. xxv. 572.

${ }^{18}$ Podmore, Moravian Church, 47-56.

19 Works of John Wesley, xxv. 586, 592-3, 595.

${ }^{20}$ Ibid. xxv. $5^{86 .}$ 
went unresolved; along with a number of other issues, it smouldered through 1738 and finally exploded in the autumn of 1739 .

\section{Fighting over stillness}

Wesley's journal entry for 12 September 1739 reads like many entries for the period of tumult that was just beginning. He wrote:

In the evening at Fetter Lane I described the life of faith, and many who had fancied themselves strong therein found they were no more than newborn babes. At eight I exhorted our brethren to keep close to the Church, and to all the ordinances of God, and to aim only at living 'a quiet and peaceable life, in all godliness and honesty'. ${ }^{22}$

This slightly cryptic entry marks the beginning of Wesley's bitter battle with the Moravians within Fetter Lane over 'stillness' spirituality. This was a distillation of elements of Moravian practice and doctrine. It fostered an attitude of passive reception of grace that required a thorough repudiation of the active, sober piety that had been the core of Oxford Methodism and which was now central to the new conversionist Methodism. Based in Lutheran theology and with debts to mysticism, 'stillness' was meant to instil inner peace as well as a sense of superiority in those who sought to hack their way to heaven through discipline, or sought grace through prayer, Scripture study or eucharistic celebration.

For Wesley, such turning away from the 'ordinances of God' was unacceptable. In his journal entry for 18 September 1739 , Wesley wrote of three different meetings, the first of which involved a young woman 'in such an agony as I have seldom seen'. Caught up in her 'sorrow and fear' the woman collapsed, groaning and sighing. Wesley's pastoral response was to urge 'the promises made to the weary and heavy laden', with the result that the woman 'saw her Saviour, as it were, crucified before her eyes. She laid hold on him by faith, and her spirit revived'.23 That evening, Wesley was again 'enabled earnestly to call all the weary and heavy laden'. Later that evening, the same message was preached to the assembly at Mrs Crouch's home, and in response, 'many roared aloud; some of whom utterly refused to be comforted till they should feel their souls at rest in the blood of the Lamb, and have his love shed abroad in their hearts'. ${ }^{24}$ The phrases Wesley uses in these brief accounts evoke a message of spiritual 'rest' for the 'weary and heavy laden'-phrases that Wesley would repeatedly use in his battle against the doctrine of 'stillness'. The significance of these events becomes clearer when seen in the light of Mrs Crouch's conversion, which occurred two days later.

As already noted, Wesley described Mrs. Crouch as being in spiritual despair, having desired to receive holy communion, where she believed

22 Ibid. xix. 96.

23 Ibid. xix. 98.

${ }^{24}$ Ibid. 
she would find 'rest to her soul'.25 According to Wesley, her spiritual 'heaviness' had been greatly increased by the 'fatal advice' of Mr. Delamotte, who had told her not to take communion until she was sure she had faith. Though Wesley does not go into further detail, Mrs Crouch's situation represented that of many associated with the Fetter Lane Society. Struggling with a sense of spiritual malaise, she faced a choice between two sets of cures, rooted in two different pieties. Charles Delamotte, a former close friend and ally of the Wesleys, supported 'stillness' doctrine. His advice reflected his diagnosis that Mrs. Crouch was 'unsaved' because of the evident increase in her heaviness of soul, a state in which there was grave spiritual danger in taking the eucharistic elements. For Wesley, by contrast, the appropriate response to spiritual heaviness was to participate in the 'means of grace', particularly eucharistic piety.

As it turned out, Wesley won this particular battle decisively, though crucially (for the polemical purpose of the narrative in his journal) he denied all agency in the matter. He described Mrs Crouch as obeying 'God rather than man'. Upon taking communion, she found Christ 'made known unto her in the breaking of the bread' and her spiritual heaviness was removed. At least as Wesley described it, this was a triumphant, instantaneous spiritual cure, complete with proper theological testimony.

In Wesley's narrative of this period, Mrs Crouch's conversion appears as the climax of a series of accounts of spiritual turmoil. These accounts establish a pattern of people recognising their need for true 'rest' (as opposed to deceptive 'stillness') and finding it in eucharistic piety and visions of the cross. Here, as elsewhere, Wesley presented spiritual experience as providing convincing evidence of his doctrinal convictions. And here, as elsewhere, if the gender of those having such experiences is mentioned, it was almost always female.

\section{Fighting over women}

The struggle between Wesleyan and stillness spirituality in the Fetter Lane Society intensified in November 1739 with the arrival of two German Moravians, Spangenberg and Molther. Phillipp Heinrich Molther (1714-8o) was waiting in London for passage to the Moravian colony in Pennsylvania, when James Hutton brought him to a meeting at Fetter Lane. Reacting with horror to the 'extraordinary usages' he encountered there, which he described as 'sighing and groaning ... whining and howling', Molther worked to strengthen the hand of those who were attempting to steer closer to Moravianism and stillness doctrine. ${ }^{26}$ In his

\footnotetext{
25 Ibid. $\quad 26$ Ibid. xix. 119 n. 2. See also Podmore, Moravian Church, 59-66.
} 
account of these events, Molther explicitly blamed John and Charles Wesley for introducing such behaviour. ${ }^{27}$

Not surprisingly, Wesley chose to bury that aspect of the conflict in his journals, instead portraying the conflict in a way more appealing to his English readers. He began the text of his third, extracted journal with a string of short anecdotes and commentary concerning the battle with the Moravians, foregrounding the question of proper eucharistic piety. For example, he cites Charles Wesley's former mentor, John Bray, as preaching 'of the great danger that attended the doing of outward works', and of 'the folly of people that keep running about to Church and Sacrament, as I (said he) did till very lately'. ${ }^{28}$

A further significant dimension of this conflict was the concerted effort of the pro-Moravian party to undermine Wesley's influence over the women within the society. He writes:

In the evening I met the women of our society at Fetter Lane, where some of our brethren strongly intimated that none of them had any true faith; and then asserted in plain terms (1) that till they had true faith, they ought to be still, that is (as they explained themselves) 'to abstain from "the means of grace", as they are called - the Lord's Supper in particular'; (2) 'that the ordinances are not means of grace, there being no other means than Christ.' ${ }^{2} 9$

Such teaching represented a direct threat to Wesley's credibility and leadership. It implied that those converted under his ministry were no converts at all. The Moravian party's rejection of the spiritual value of 'the ordinances' imperilled his attempts to create a movement that could claim fidelity to Anglicanism. And their teaching struck at key aspects of his relationship with the female members of his society, not the least the way he had relied upon supernatural confirmations of his teaching that had come through dramatic deliverances of women. From Wesley's perspective this teaching was initially highly successful. 'Till Saturday the tenth', he claimed, 'I think I did not meet with one woman of the society who had not been upon the point of casting away her confidence in God.'3o

At this moment of crisis, it was again the experience of a woman that proved decisive. On 10 September, Wesley reported, he found a woman who, in spite of Moravian attempts to persuade her otherwise, was sure that she lived 'by faith in the Son of God'. She testified that 'he has never left me one moment, since the hour he was made known to

${ }^{27}$ See Molther's account in Memoirs of James Hutton comprising the annals of his life and connection with the United Brethren, ed. Daniel Benham, London 1856, 53 .

${ }_{28}$ Works of John Wesley, xix. $119 . \quad{ }^{29}$ Ibid. $\quad 30$ Ibid. xix. 120. 
me in the breaking of the bread'. For Wesley, this was the proof that he required:

What is to be inferred from this undeniable matter of fact-one that had not faith received it in the Lord's Supper? Why, (1) that there are 'means of grace', i.e. outward ordinances, whereby the inward grace of God is ordinarily conveyed to man, whereby the faith that brings salvation is conveyed to them who before had it not; (2) that one of these means is the Lord's Supper, and (3) that he who has not this faith ought to wait for it in the use both of this and of the other means which God hath ordained. ${ }^{1}$

Wesley had managed to find at least one woman willing to bear witness to the reality of the spiritual truths of which he spoke. Interestingly, the following journal entries imply that Wesley was involved in intensive personal lobbying as well as aggressive public preaching in order to identify those who would bear such testimony and thus supply him with badly needed credibility. $3^{2}$

The conflict between the Wesleyan and Moravian parties within the society gained strength over the following six months, as the Wesleys' relative success in securing the loyalty of women converts became ever clearer. Early in 1740 Hutton wrote to Zinzendorf, expressing his concern that the German Moravian women in London did not speak English well enough to provide leadership for the women in the Society. 33 Zinzendorf replied in April, asking for English sermons to be sent to Herrnhut so that women there could learn English. This lack of female leaders among the Moravian contingent in England was a serious barrier to attempts to create the kind of parallel structures which were so effective in Herrnhut and elsewhere.

None the less, during the same period, while the Wesley brothers were both away from London, Hutton and the other Moravian leaders imposed strict gender segregation within the Fetter Lane Society over the protests of at least some of the women. Charles Wesley, in London during early April, wrote that he and his supporter Thomas Maxfield were shut out of the band meetings by the pro-Moravian leadership. According to Charles, John Bray had 'denounced grievous woes against the women, for suffering Maxfield to be present, contrary to order. That order, [the women] said, had been imposed upon them when no Minister was present'.34 When Maxfield and Charles next attended the Fetter Lane Society, James Hutton 'welcomed Maxfield by telling him, "if you ever speak to any of the women as you used to at Bristol, you must not come here"' .35

In the midst of the conflict, James Hutton went to visit the continental Moravians. Once there he was urged to marry a Swiss woman named Louise Brandt, with the express purpose of shoring up the capacity of the

$3^{1}$ Ibid. xix. $121 . \quad 3^{2}$ Ibid.

34 CWJi. 209, entry for 6 Apr. 1740.
33 Memoirs of James Hutton, 49-50.

35 CWJi. 212 , entry for 9 Apr. 1740. 
London Moravians to minister to women in London. The wedding took place on 3 July 1740 , but it would be two years before Louise was able to report back to Herrnhut that she had become fluent enough in English to minister to bands of Englishwomen. $3^{6}$

Just seventeen days after the Huttons were wed, on 20 July 1740 , formal division occurred when John Wesley led a division within the Fetter Lane Society. His journal entry for 23 July reads:

Our little company met at the Foundery instead of Fetter Lane. About twenty-five of our brethren God hath given us already, all of whom think and speak the same thing; seven or eight and forty likewise of the fifty women that were in band desired to cast in their lot with us. 37

Of the fifty highly-committed women whom Wesley recorded as belonging to the band structures at the time, he claimed to have retained the loyalty of at least forty-seven.

The Wesleys' success in securing the loyalty of the women of the society is confirmed by comments from the Moravian side of the conflict. Hutton noted that when the Wesleys left the Fetter Lane Society 'Many of our usual hearers consequently left us, especially the females.' ${ }^{8}$ Elsewhere, Hutton accused the Wesley brothers of being 'snares to many young women' who were in love with them, famously adding 'I wish they were married to some good sister, but I would not give them one of my sisters if I had many.' 39 Similarly, in an exchange of letters that followed the split, continental Moravians poured scorn on the Wesleys' followers and their spiritual testimonies, dismissing them as 'a certain sort of woman', who had been converted to the Wesleys rather than 'to the Saviour'. $4^{\mathrm{o}}$

While John Wesley's problematic relationships with women undoubtedly provided some fuel for such accusations, Hutton and his coreligionists were writing as partisans who felt that close pastoral contact between the sexes, a defining feature of the Wesleyan group, was inherently immoral. Like some modern scholars they attempted to explain away the attractiveness of Methodism to women by pointing to women's inherent emotionalism or susceptibility to a pretty male face..$^{1}$ Such explanations rarely address or take seriously women's own accounts of their choices.

$3^{6}$ Memoirs of James Hutton, $5^{6-8}, 64,68$.

37 Works of John Wesley, xix. 162-3.

$3^{8}$ Memoirs of James Hutton, 54 .

39 mss Herrnhut R.13. A.7. Ro25, quoted in W. R. Ward, The Protestant Evangelical awakening, Cambridge 1992, 313 .

$4^{\circ}$ Works of John Wesley, xxvii. 40.

$4^{1}$ For more modern versions of this argument see Henry Abelove's deeply Freudian reading of early Methodism in John Wesley: evangelist of desire, Stanford 1990, or E. P. Thompson's dismissal of Methodist women in The making of the English working class, London 1980, 404-5. 


\section{Women's voices}

Why did so many women choose to reject the pro-Moravian leadership and follow the Wesleys out of the Fetter Lane Society? It seems likely that women may have appreciated the Wesleys' defence of their involvement in the main meetings of the Society. However, a range of other motives emerges in spiritual testimonies collected by the Wesley brothers at the height of the conflict, especially a selection collected by Charles Wesley from women involved with the Society in March-June 1740, eight to ten of which are extant. $4^{2}$ A year later, he received six letters from men in London who had also rejected 'stillness' doctrine the previous year. The relatively few letters we have cannot provide definitive proof of why men and women chose to follow the Wesleys, but certain themes stand out.

In the first place, these testimonies point to the significance of the Wesleys' personal ministry in women's lives. Repeatedly, the women recounted powerful experiences, including overwhelming guilt, grief, trembling, visions of Jesus and intense joy, while hearing either or both of the brothers preach or pray.43 'I heard you, sir', wrote Margerit Austin 'and there I plainly saw my Saviour bleeding on the cross, and soldiers piercing his precious side, and the blood falling to the ground. Oh, thought I, that I had but one drop of that blood to wash away my sins.' 44 However such experiences were almost always reinforced by personal contact with the brothers in individual conversations and times of prayer.45 After Austin heard Charles preach again, and experienced 'great joy', she went to speak with him in person. 'You told me I was justified', she noted, 'I found your prayer very helpful that morning.' $4^{6}$ Three days later, Austin heard Charles read an account of his conversion and pray, and the following morning she wrote "the voice of the Lord said to me, "Thy sins are forgiven" twice over.... Then I felt old things passing away and all things becoming new'.47 These women testified that this combination of public and personal ministry had resulted in spiritual deliverance (often, but not always, deliverance from the overwhelming guilt and fear that Wesleyan preaching itself had triggered).

$4^{2}$ These letters are held in the EMV.

43 See, for example, Mariah Price to Charles Wesley, 8 May 1740, EMV, Ms 12; Margerit Austin to C. Welsey, 19 May 1740, Ms 1; S. Ibson to C. Wesley, 23 May 1740, ms 8; Sarah Middleton to C. Wesley, 25 May 1740, Ms 5; Elizabeth Hinsom to C. Wesley, May 1740, ms 2b; Mary Ramsey to C. Wesley, 4 June 174 o, Ms 3.

44 Austin to C. Wesley, ibid. Ms 1.

45 See, for example, Price to C. Wesley, ibid. ms 12 ; Austin to C. Wesley, Ms 1 ; Ibson to C. Wesley, ms 8; Middleton to C. Wesley, ms 5; Martha Jones to C. Wesley, 1 June 1740 , Ms 3; Ramsey to C. Wesley, ms 13 .

$4^{6}$ Austin to C. Wesley, ibid. MS 1.

47 Ibid. 
Though hostile contemporaries and modern critics have portrayed the bonds between the Wesleys and their followers as expressions of suppressed sexual attraction, the accounts written by the women demonstrate a strongly filial bond with the Wesleys that is closely related to their status as Anglican priests. 'My dear father in God', Mariah Price began her account, 'I now declare unto you with a joyful heart, as well as I can remember, how Lord worked in my soul by you, my own Father.' 'Dear sir', she concluded, 'I am your own daughter in God.' $4^{8}$ Such language was typical.49 Charles Wesley noted, in a more striking image, that Margerit Austin told him that she had longed for his visit to London 'as a child for the breast'. $5^{\circ}$ Charles Wesley was often addressed in these letters as 'reverend father' or 'reverend sir', suggesting that his status as a priest had significance in the women's perception of him as spiritual father. $5^{1}$ 'Reverend Sir', Mary Ramsey wrote, 'I beg leave to subscribe myself one of your young babes in Christ.' 52 While the title 'Reverend' may seem a mere formality, it is noteworthy that all eleven women who wrote from London to Charles Wesley in this period addressed him either as 'reverend' or as 'father', often both. By contrast, of the seven men who wrote to Charles the following year, describing their experiences during this earlier period, only one addressed him as 'Reverend' and none as 'father'. Instead, they repeatedly addressed him as 'brother'. 53

A second, closely related theme within the letters of both men and women is that of sacramental piety. Many of the writers note that the eucharist formed an integral part of their experience of spiritual conviction and conversion. Mary Ramsey spoke of the 'manifestations' that she received while taking the sacrament: 'I stood as if Christ was just there on the cross and his blood descending into my heart.'54 After hearing Charles preach and pray at Kennington Common, a Mrs Ibson wrote that she took the sacraments for the first time, something that she had always longed to do, but of which she had never felt worthy. She doubted that her sins could be forgiven, but wrote: 'notwithstanding all my

$4^{8}$ Price to C. Wesley, ibid. Ms 12.

49 See also Austin to C. Wesley, ibid. ms 1; Sarah Barber to C. Wesley, May 1 740, ms 7; Ramsey to Wesley, Ms 13 . $5^{\circ}$ CWJi. 210 , entry for 6 Apr. 1740 .

$5^{1}$ See Elizabeth Bristow to C. Wesley, 12 Apr. 1740, EMV, ms 11 ; Austin to C. Wesley, mS 1; Middleton to C. Wesley, ms 5; S. Barber to C. Wesley, ms 7; Jones to C. Wesley, ms 3; Ramsey to C. Wesley, ms 13 . $5^{2}$ Ramsey to C. Wesley, ibid. Ms 13.

53 Samuel Webb to C. Wesley, 20 Nov. 1741, ibid.; Taverner Wallis to C. Wesley, 27 Nov. 1741 (no ms number); Joseph Carter to C. Wesley, Nov. 1741, MS 17; James Flewitt to C. Wesley, Nov. 1741, ms 14; Thomas Cooper to C. Wesley, 1741 (no ms number); Nathaniel Hurst to C. Wesley, 1741 (no Ms number).

54 Ramsey to C. Wesley, ibid. ms 13. 
doubts and fears I received it and I was filled with love as well as joy'.55 Soon afterwards, at a meeting where Charles preached:

You spoke something of the holy sacrament. It came with such power into my soul that I prayed 'Oh that I might receive it from your hands, then I should be free indeed.' For I knew I had received so many gifts from my dear Saviour by your preaching and prayers.

Following the meeting, Charles invited Ibson to visit a sick woman with him. While there, he administered the sacrament and the sick woman experienced the forgiveness of sins. Mrs Ibson recorded that again she 'was filled with love as well as joy, so that I prayed for all and I wept to see so many dead people in the streets'..$^{6}$ This account provides a revealing example of how the personal ministry of the Wesleys, combined with their priestly role and a person's existing sense of the spiritual power of the sacraments, could evoke powerful experiences.

Though the women's letters were written before the final split within the Fetter Lane Society, many of the women mention the sacraments in conjunction with the conflict over 'stillness' teaching. Margerit Austin wrote that one of the London preachers declared to the Wesleyan party that 'if we read, the devil read with us; and likewise, if we prayed, he prayed with us, and when we went to church for sacrament, the devil went with us'.57 As a consequence, she gave up praying and going to the sacrament for some time, until convinced by Scripture that she should once again attend the Lord's Supper. She wrote that as she finished taking the sacraments, 'I saw Christ lay with his open side, and I thought I could see his heart bleeding for me. ${ }^{5}{ }^{8}$ Similarly, after mentioning her fear of 'going into that stillness that was talked of', Sarah Barber commented that 'the Lord gave me power' to take the sacraments and there she received confirmation from the 'voice of the Lord' that she was doing right. 59

These accounts and others like them suggest that women were deeply loyal to the Anglican sacraments, experiencing supernatural confirmation of their efficacy that justified their rejection of the Moravian doctrine of 'stillness'. ${ }^{6}$ For those loyal to the Church of England, the Moravian teaching represented a departure from orthodoxy, as Martha Jones noted:

I would not consent to leave the ordinances though they said we should not go to church nor pray nor receive the sacrament. These things shocked me, not that

55 Ibson to C. Wesley, ibid. ms 8.

$5^{6}$ Ibid.

57 Austin to C. Wesley, ibid. Ms 1. $5^{8}$ Ibid. 59 S. Barber to C. Wesley, ibid. ms 7.

6o See also Jones to C. Wesley, ibid. Ms 3, and Ramsey to C. Wesley, Ms 13. 
I trusted in any of these things, God by your ministry had taught me better. It was Jesus Christ I wanted and him only I sought in them. But indeed I feared these men were bringing another schism into our church. ${ }^{61}$

Three of the men's narratives from $174^{1}$ also bear witness to experiences of the saving power of the sacraments, though this theme is less dominant. ${ }^{62}$ Both William Barber and Thomas Cooper recorded that they had received the new birth while taking the Lord's Supper and had resisted the advocates of 'stillness' spirituality. What can these observations tell us about the split within the Fetter Lane Society in 1740, and particularly about the stark gender imbalance between those who chose to remain and those who left with John Wesley? The surviving accounts strongly suggest that those who chose to follow the Wesleys did so because they valued them highly as ordained priests of the Church of England who were loyal to the sacraments and spirituality of High Church Anglicanism. Such loyalty to the Church of England, its ministers and sacraments is not surprising within the context of eighteenth-century England, where the cultural and social power of the Church of England remained strong. However, given that many of those within the Fetter Lane Society were willing to follow the Moravians in turning away from both the sacraments and the priesthood, the capacity of the Wesleys to represent this cultural power was significant. In addition, if the accounts of the period written by the Wesleys are any indication, women seemed far more likely than men to experience ecstatic manifestations of the power of the sacraments, and the letters sent to Charles Wesley bear this out. The letters also seem to demonstrate that women did experience manifestations of the "means of grace' like those that the Wesleys reported, and that these experiences were closely related to a sense of esteem for the Wesley brothers as ministers of those very Anglican sacraments.

The letters point to one more factor influencing women's choices. Though one might not guess it by reading John Wesley's accounts of the split, these letters and other sources make it clear that lay leaders were active and successful lobbyists, amplifying the gender divide. The most prominent laymen in the Fetter Lane Society, including John Bray and the society's co-founder James Hutton, were strongly supportive of Moravian spirituality and leadership. Furthermore, John Edmunds, the leader of the men's band, became a founding member of the London Moravian congregation. ${ }^{63}$ By contrast, Mary Robinson, the leader of the women's band, rejected the 'stillness' doctrine, was loyal to the Wesleys and

61 Jones to C. Wesley, ibid. Ms 3.

${ }^{62}$ William Barber to C. Wesley, 1741, ibid. (no ms number); Cooper to C. Wesley; Hurst to C. Wesley.

${ }^{6}$ D. Bruce Hindmarsh, The Evangelical conversion narrative: spiritual autobiography in early modern England, Oxford 2005, 132. 
presumably left Fetter Lane with them. Judging by the extant letters, she appears to have played a significant role in drawing the women of the society away from 'stillness' spirituality and reinforcing their loyalty to the Wesleys. Writing to Charles Wesley, Margerit Austin recounted that when she was first convicted of her sin, she went to 'Sister Robinson' who 'bestowed much pity on me, prayed and comforted me very much. I told her my state, and she told me how she had received faith under the ministry and by the prayers of you, sir' ${ }^{6}{ }_{4}$ Sarah Barber wrote that, when tempted by Satan to believe that she could not be justified, 'Sister Robinson would often bid me not believe him. Then I hoped and found comfort.' Later, Sister Robinson assured her that the peace she felt was not 'stillness' but 'the peace of God' and that she 'was in a very safe state'. ${ }^{6}$ Mary Ramsey commented that she found 'much comfort in the meetings at Sister Robinson's'. ${ }^{66}$

Robinson was not the only female lay-leader working to drum up support for the Wesleys. A Sister Jane Jackson is often mentioned in Charles Wesley's unpublished journals as an encourager or public supporter, as was Jane Muncy, who also strongly resisted the effort to bar 'her ministers' from leading the women's bands. ${ }^{67}$ The influence of Mary Robinson, Jane Jackson and Jane Muncy highlights the fact that women's lay leadership was a fundamental building block of the Methodist movement. In early $174^{2}$ Wesley's list of class leaders in his new society at the Foundery showed that women leaders outnumbered men by well over two to one. ${ }^{68}$ From the start, Wesleyan Methodism was extremely dependent upon lay leaders, many of them women bound together by close spiritual friendships. ${ }^{69}$

John and Charles Wesley practised a form of ministry that excelled in providing and interpreting experiences of conversion and spiritual deliverance-particularly to women. The authority and credibility thus derived was vital to the Wesleys, but their methods and supporters came under harsh critique in the course of their battles with James Hutton and other men of the Fetter Lane Society. Hampered by their observance of the Moravian practice of gender separation and the lack of English-speaking Moravian women in London, Moravian leaders like Hutton lagged far behind the Wesleys in gaining the loyalty of the women of the society.

The 'stillness controversy' which wracked the Fetter Lane Society from late 1739 , involved a number of related tensions between the Wesleys and

\footnotetext{
64 Austin to C. Wesley, EMV, Ms 1.

66 Ramsey to C. Wesley, ibid. Ms 13.

65 S. Barber to C. Wesley, ibid. Ms 7.

67 CWJi. 234, 237.

68 Wesley recorded the names of nineteen men and forty-seven women in his list of leaders at the Foundery: G. J. Stevenson, History of City Road Chapel, London 1872, 29.

69 For the significance of women's friendships in English Methodism see Mack, Heart religion, and Joanna Cruickshank 'Friend of my soul': constructing spiritual friendship in the autobiography of Mary Fletcher', Journal of Eighteenth-Century Studies xxxii (2009),
} $373-87$. 
the Moravians regarding the role of supernatural experience and the appropriate place of sacramental observance. These tensions became inextricably linked to questions of gender. The Moravian leadership actively sought to win over women loyal to the Wesleys, primarily by discrediting Wesleyan conversions and deliverances. In the intense personal lobbying that followed, the Wesleys received vital assistance from a handful of women lay leaders, including Mary Robinson, Jane Jackson and Jane Muncy. Facing defeat in the spring and summer of 1740 , Hutton and the other Moravians attempted a number of measures to neutralise the Wesleys' advantage in securing the loyalties of women, including Hutton's marriage and the imposition of gender segregation on the Society while the Wesley brothers were both out of town. $7^{\circ}$

The fact that virtually all the women of the Fetter Lane Society followed John Wesley when he walked out on 20 July $174^{\circ}$ has led both his contemporary opponents and later historians to speculate that sexual attraction may have played a significant role in the event. However, surviving accounts of Methodist women's own viewpoints demonstrate a strong correlation between their attachment to the Anglican sacraments, their loyalty to the Wesleys as Anglican priests and their experiences of spiritual deliverance and transformation. They also provide evidence of women's active and influential involvement in leadership and lobbying during this critical time. It was Mrs Crouch and women like her whose choices helped to determine that Wesleyan Methodism would survive in London. The Wesleys' reliance on women during this period left them open to criticism, but over the next half century it proved a powerful religious force and a source of new opportunities for women.

$7^{\circ}$ On the defining conflicts between Moravians, Wesleyans and Calvinistic Methodists see further Brian Curtis Clark, 'The contentious birth of Wesleyan Methodism, 1738-1741: gender, charism, and sectarian division', unpubl. PhD diss. Boston 2008. 